\title{
Supplementing the European Convention on Human Rights: legislating for positive obligations

\author{
DR DAVID RUSSELL*
}

Northern Ireland Human Rights Commission

\section{Introduction}

$\mathrm{E}$ ffective enforcement and implementation is a concern for any human rights legislation. Deciding where the obligations lie to promote, protect and fulfil rights and, in particular, what the reach of those obligations ought to be with respect to both public and private organisations are issues of crucial importance. Without these decisions having been taken, the scope of application of the legislation may be open to challenge and those with a duty to uphold rights may be ignorant of their responsibilities, or at the very least be less likely to interrogate what their obligations are in a meaningful sense. An equally important decision relates to the nature and extent of obligations and, in particular, what level of responsibilities should be imposed upon those who bear a duty to uphold rights. Here, too, the risk is that if the obligations imposed on duty-bearers are not explained clearly enough then there may be less diligence afforded to protecting human rights and so violations are ultimately more likely to occur. In this paper, I consider how the European Convention on Human Rights (ECHR) can help provide us with answers to these two questions. Who should be obliged to uphold rights? And what actions do those obligations require?

In theory, the Convention is a framework that is primarily concerned - although not exclusively so - with defending human rights conceived as negative liberties and that, therefore, requires governments to act as the guarantors of non-interference in the free choices exercised by individuals. ${ }^{1}$ However, a principled reading of the Convention combined with case law from the European Court of Human Rights (ECtHR) allows us to make a convincing argument showing that the Convention offers much more than a defence of negative liberty. In particular, such an argument shows that the Convention should also be understood as a framework that is concerned with promoting human rights as positive obligations requiring duty-bearers to take certain actions to uphold our liberties. This point has been too often overlooked. The thesis in support of positive obligations remains underdeveloped and this has diminished the effectiveness of the Convention and its application within the domestic jurisdictions of contracting states.

* Head of Communications and Education at the NIHRC and a board member of the Northern Ireland Community Relations Council. The author would like to make clear that this article is written in a personal capacity and does not reflect the opinion of any organisation to which he is affiliated.

1 This is not to deny acceptable qualifications and limitations introduced by a democratic government, for example, to balance competing rights or to protect the broader public interest. 
By applying a principled approach which reads the Convention as imposing some positive obligations, it is possible to arrive at a position where human rights can be better protected. Since positive obligations highlight the responsibilities that governments and other executive agencies have to take pro-active measures to protect rights, it follows that their introduction means that duty-bearers will in practice need to make interventions to pre-empt human rights violations and provide necessary redress whenever violations occur. Utilising this approach, I will illustrate in the following paper how innovative solutions can be developed to answer the questions of who should be obliged to uphold rights and what actions those obligations require. Central to my argument will be the idea of "contextsensitive legislation". Such legislation is required in the respective jurisdictions of contracting states so as to spell out the sorts of positive obligations that might have purchase for people and that will resonate with their experience of everyday life.

On the face of it, of course, there appears to be an obvious contradiction here. On the one hand, this paper will examine the general principles that support reading the Convention as a text that asserts positive obligations, while, on the other, the paper will argue in favour of a context-sensitive approach. But while this might sound contradictory, it is not. At one level, I will argue that we can identify general principles that underpin a reading of the Convention that includes positive obligations. Yet, when it comes to seeing how those principles play out in particular jurisdictions, I will also argue that we are compelled to shift from a theoretical level of reasoning to a level of reasoning that is much more sensitive to conditions on the ground.

One should not draw a bright line between these two arguments. How general principles play out in practice will contribute to and inform our ongoing theoretical reflections. In this sense, the paper assumes that theory and practice are mutually implicating - general principles imply practical questions, just as practical questions require us to take a reflexive attitude toward our general principles. By way of illustration, I use the case of Northern Ireland, where deliberations have recently taken place on supplementing the Convention with a Bill of Rights. In particular, I show how an argument can be made to include a wider range of public and private organisations as duty-bearers by extending the scope of application. Once this has been achieved, I will demonstrate how it becomes possible to point towards a typology for positive obligations, one that reflects and further develops the general principles that underpin it.

\section{A principled approach}

The scheme of the ECHR is to set out rights and freedoms and then determine the circumstances, if any, in which they may be restricted. For the most part, this approach is concerned with shielding individuals from undue interference by the state and its representatives, with limited qualifications. What Isaiah Berlin referred to as "negative liberty" is therefore a central value of the Convention as it seeks to guarantee that human rights are framed as a safeguard against arbitrary government. ${ }^{2}$ It is, in sum, a treaty that appears at first to be underpinned by a particular concept of liberty definable in terms of a requirement of non-interference on behalf of contracting states. The obligation on governments to resist the introduction of obstacles, barriers or constraints that would prevent individuals from exercising their rights without justifiable cause and, even then, only in certain pre-determined circumstances, is in many respects the Convention's mantra. ${ }^{3}$

2 I Berlin, "Two concepts of liberty" in H Hardy (ed.), Liberty (Oxford: OUP 2002).

3 For further discussion, see J G Merrills, The Development of International Law by the European Court of Human Rights (Manchester: Manchester University Press 1993), p. 103, and D Feldman, Civil Liberties and Human Rights in England and Wales 2nd edn (Oxford: OUP 2002), p. 53. 
The actual jurisprudence of the ECtHR suggests, however, that duties imposed by the Convention are much wider than a concept of negative liberty could alone provide for. In the process of protecting and promoting rights and freedoms, due regard must, we are told, be afforded to the "special character" of the Convention as "a treaty for the collective enforcement of human rights". ${ }^{4}$ Such regard depends for its success on a further determination that the Convention should operate as a guarantee for the enforcement of rights that are not theoretical or illusory but "practical and effective". 5 This in turn has been interpreted by the Court to mean that states are not only required "to refrain from action" that would amount to an undue or unjustifiable interference in an individual's exercising of his or her rights, but also to recognise that the Convention imposes upon governments the positive obligation "to take action" in order to protect rights in ways that enable claimants to realise them in practice. 6

A requirement to take action is perhaps most readily identifiable when it comes to ensuring the right to a fair trial. Article 6(3), which guarantees that everyone charged with a criminal offence receives state assistance, amounts to much more than a duty to uphold the concept of negative liberty. It also demands that procedures and resources - including financial support such as legal aid - should be introduced by governments to ensure that individual claimants have the capacity to exercise their rights in a meaningful sense. While positive obligations are therefore expressly defined within the text, this is not typical of the Convention as a whole. Instead, positive obligations to take action have more usually evolved as a consequence of judicial interpretation rather than express reference. So, for example, the right to life has been interpreted to include a duty to take proactive measures to prevent a violation from occurring ${ }^{7}$ and to effectively investigate suspicious deaths. ${ }^{8}$

It is important, however, not to overstate this point. While the ECtHR has declined to expressly develop any normative standards, Keir Starmer has argued that there are sufficient grounds, nonetheless, drawing from both the text and case law, to identify a set of principles that support the dominant judicial view of the Convention as a framework for the imposition of positive obligations. ${ }^{9}$ The first of these principles requires contracting states to take actions to secure Convention rights for everyone within their jurisdiction. Premised upon Article 1, it necessitates, amongst other actions, the creation of domestic legal frameworks which can provide effective protection for Convention rights. It also includes a duty to allocate resources to individuals in order to prevent violations of their rights and the provision of information and advice on both the content of the Convention itself and on issues (such as government policies or the activities of private organisations) the consequences of which might adversely impact individual claimants. ${ }^{10}$

A second principle, which I have already mentioned briefly, requires actions to guarantee that rights are both practical and effective. This is premised on case law ${ }^{11}$ and demands the

4 Soering v UK (1989) 11 EHRR 439, para. 87.

5 Artico v Italy (1980) 3 EHRR 1. See also, K Starmer, European Human Rights Law (London: LAG Education and Service Trust Ltd 1999), pp. 158-9.

6 Gülv Switzerland (1996) 22 EHRR 93, dissenting opinion of Judge Martens, para. 7.

7 McCann and Others v UK (1995) 21 EHRR 97, paras 146-7; Osman v UK (2000) 29 EHRR 245, para. 151; Anguelova v Bulgaria (2004) 38 EHRR 31, para. 109.

8 Kelly and Others v UK App. No 30054/96, 4 May 2001, para. 154; Ergi v Turkey (2001) 32 EHRR 18, para. 98; Salman v Turkey (2000) 34 EHRR 425, para. 123; McKerr v UK (2002) 34 EHRR 20, para. 111.

9 Starmer, European Human Rights Law, n. 5 above, pp. 193-209.

10 Ibid. pp. 196-9, 202-4.

11 A Mowbray, The Development of Positive Obligation under the Eurpoean Convention on Human Rights by the Eurpoean Court of Human Rights (Oxford and Portland, Oregon: Hart Publishing 2004). 
introduction of preventative and proactive measures that are designed to protect individuals from the actions of other individuals or those of public and private organisations. Such a requirement has resource implications. As Rabinder Singh notes:

$[\mathrm{P}]$ rotection has a price. The right of access to the courts would be meaningless if there were no courts, or if they were not properly financed, or if only a few people could get to them owing to a lack of money. ${ }^{12}$

Still, the reach of this principle, as I have indicated, goes far beyond the realisation of Article 6 and could easily be read into much of the Convention, as well as changing our understanding of the text. So, for example, the Court has determined that:

the Convention must be interpreted in light of present day conditions . . . [ ] t is designed to safeguard the individual in a real and practical way as regards those areas with which its deals. Whilst the Convention sets forth what are essentially civil and political rights, many of them have implications of a social or economic nature. ${ }^{13}$

The third principle identified by Starmer requires actions to be taken to secure effective remedies in the event of there being a violation of human rights. Premised on Article 13, the demand made in this instance is one of compliance by guaranteeing that where a violation has occurred the individual claimant will "have an effective remedy before a national authority". ${ }^{14}$ This point is significant. While the first principle - securing Convention rights for everyone within the jurisdiction - may be interpreted as requiring the introduction of a domestic legal framework, it remains in many respects a minimum requirement. There is no obligation, for example, following this first principle, to incorporate the Convention directly into domestic law. By comparison, the third principle does impose an express duty to give domestic force to Article 13. This has been interpreted to include not only the payment of compensation when a violation has taken place, but also the execution of an effective investigation leading to criminal prosecutions where appropriate. ${ }^{15}$

Taken together, the three principles as I have outlined them are useful in assisting us to identify the sorts of actions that, at a general or theoretical level, might be used in order to give the Convention meaning as an enforceable human rights framework. ${ }^{16}$ In a sense, one might argue, as Starmer has done, that the principles themselves amount to positive obligations. Certainly, once attached through an interpretative exercise to existing human rights, it becomes possible to formulate a series of associated responsibilities to take actions deemed necessary to guarantee that the rights in question are practical and effective. This may, admittedly, shine a light on areas of law that are in need of further definition. Yet, the approach adopted by the Court of imposing positive obligations as a consequence of interpretation is less than optimal. Let me explain why.

When a case is presented before the ECtHR, the Court has often ruled on how and to what extent a government is obligated to take action. This activity is, on one reading, entirely fit for purpose. But judicial behaviour of this sort can never be a sum total and should only be considered legitimate when it is understood to be part of a broader

$12 \mathrm{R}$ Singh, The Future of Human Rights in the United Kingdom: Essays on law and practice (Oxford and Portland, Oregon: Hart Publishing 1997).

13 Merrills, Development, n. 3 above, p. 102.

14 Article 13 ECHR.

15 K Starmer, "Positive obligations under the convention" in J Jowell and J Cooper (eds), Understanding Human Rights Principles (Oxford and Portland, Oregon: Hart Publishing 2001), p. 156.

16 It is an open question as to whether these principles would also be the appropriate for a legislature to decide how to enforce the convention, but in essence this is precisely the question I am attempting to answer in this paper. 
democratic process. If one were to leave it entirely to a court to decide who should be obliged to uphold rights and what actions those obligations require, then we would be left with, as Albert Weale suggests, "a large penumbra of uncertainty surrounding individual legal obligations". ${ }^{17}$ This is not because legal judgments lack clarity. It is because a court can only react to social problems once they have emerged, rather than anticipate them. A court may be able to pass judgments on individual claims, but as Weale goes on to argue, it "lacks the capacity to deal with the cumulative, unintended effects of individual behaviour". ${ }^{18}$ More generally still, a court can only indirectly shape the social backdrop within a society, against which claims of rights violations emerge, but is not itself well placed directly or preemptively to change that backdrop; it is simply not part of a court's remit to engage in acts of societal interpretation on this ontological scale (although, of course, it may contribute to such interpretation indirectly or on a smaller scale). All of this is just to say that, if we wish fully to address the questions of who should be obliged to uphold rights and what actions those obligations require, then we cannot simply look to what the ECtHR has said.

Addressing questions raised by the debate on positive obligations requires us to take a broader democratic view. It would be unsatisfactory to focus solely upon the judiciary. But that is not to deny the proper role of the Court, it is merely to recognise that, although the Convention has been interpreted to include positive obligations, to appreciate fully what positive obligations involve we need to look beyond the Court. Starmer, at the beginning of his essay, recognises that there may no longer be any question of whether the Convention imposes positive obligations, but there certainly are questions of when and to what extent. ${ }^{19}$ Case law provides some of the answers to these questions, but it cannot provide all of them. In fact, it may not be the best way of going about the task at hand.

In short, if it were possible to know in advance the kind of things that the Court would have to deal with, then it seems reasonable to assume that, in principle at least, domestic legislatures would make attempts to introduce laws and policies that might pre-empt and prevent human rights violations from occurring. In other words, they would voluntarily spell out positive obligations and give them legal effect. Naturally, this is not to suggest that domestic legislatures are a foolproof mechanism: they most certainly are not. But the point remains that a democratic society needs a legislature, or a legislative function, even if that function will also need to be scrutinised by the courts. It would arguably be much better and preferable, therefore, if contracting states and, in particular, their legislative and executive agencies, applied Starmer's principles and in doing so created practical and effective human rights frameworks within their respective jurisdictions from the off. This is precisely what the Belfast (Good Friday) Agreement envisaged happening in the case of Northern Ireland when it called for the Convention to be supplemented with a regional Bill of Rights. The process of creating such a Bill would require further definition to be provided both in terms of who should be obliged to uphold rights and what actions those obligations require. Each of these I would now like to consider in turn.

\section{Where the burden of responsibility should fall}

While Starmer has provided principles for thinking about positive obligations, the fact is, as I have explained, that they present little more than general guidance for thinking about how human rights ought to be applied. They can help us to understand, for example, the views adopted by the ECtHR when it has interpreted the Convention, but we are still left

17 A Weale, Democracy: Issues in political theory (Basingstoke: Palgrave 1999), p. 51.

18 Ibid. p. 5.

19 K Starmer, "Positive obligations", n. 15 above, p. 140. 
wondering how positive obligations might play themselves out within particular jurisdictions. For instance, the domestic legislative framework for implementing and enforcing the ECHR within the United Kingdom, and hence within Northern Ireland, is the Human Rights Act 1998. Since the Act came into force in 2000, it has been applied vertically and therefore imposes a direct duty to protect rights only upon those organisations defined as public authorities. ${ }^{20}$ This includes "a court or tribunal and any person certain of whose functions are functions of a public nature". ${ }^{21}$ What constitutes a public authority for the purposes of the Act has, however, been a subject of some dispute.

Attempts have been made, as noted by Ian Leigh and Roger Masterman, to extend the scope of application of the Human Rights Act so as to include private, community and voluntary organisations that have entered into contractual arrangements to deliver frontline public services and that are to that extent controlled by government departments, executive agencies or local authorities. ${ }^{22}$ On the one hand, this move has emerged in response to the practical impacts of privatisation, the introduction of public-private partnerships, and the increased tendering out of responsibilities for public service provision. But it has also crucially followed in the wake of the judiciary's demonstrable tendency to interpret the definition of a public authority more narrowly than appears to have been intended by the Westminster Parliament. ${ }^{23}$ So, for example, the decision in the YL case in 2007 that private nursing care-homes did not constitute public authorities ${ }^{24}$ was quickly followed with a legislative correction included in the Health and Social Care Act 2008 to ensure that vulnerable older people would not be adversely impacted as the consequence of a privatised public service. $^{25}$

Related to the problem of defining a public authority has been a second debate concerned with determining at what point public and private organisations must take cognisance of their responsibilities. This too has been narrowly interpreted, with the House of Lords ruling that the focus must be outcome-based. ${ }^{26}$ Provided the practical effect - the outcome - of public authority decisions complies with those aspects of the Convention included in the Human Rights Act, it has been deemed unnecessary for public authorities to prove that they have given due regard to their obligations in the process of making those decisions. This ruling stands, despite the fact that the courts have previously found in favour not only of outcome-based obligations, but also those that are process-based and which therefore require consideration of human rights compliance during the period of deliberation prior to a decision being made. ${ }^{27}$ An outcome-based focus, rather than processbased one, lessens the burden of responsibility. It leans towards a negative liberty interpretation of human rights in general, whereby those representing the state need only

20 This is not to deny the fact that indirect horizontal application has also been afforded on occasion as a consequence of the courts' developing the common law in line with convention rights.

21 Human Rights Act 1998, s. 6(3).

22 Ian Leigh and Roger Masterman, Making Rights Real: The Human Rights Act in its first decade (Oxford and Portland, Oregon: Hart Publishing 2008), p. 134.

23 See, for example, HC Debs, col. 773, 16 February 1998, where Mr Jack Straw, during the second reading of the Human Rights Bill, noted that: "The Bill had to have a definition of a public authority that . . took account of the fact that, over the past 20 years, an increasingly large number of private bodies, such as companies or charities, have come to exercise public functions that were previously exercised by public authorities." YL v Birmingham City Council [2007] UKHL 27, [2008] 1 AC 95.

25 Health and Social Care Act 2008, s. 145 (1).

26 Belfast City Council v Miss Behavin' Ltd [2007] UKHL 19; [2007] 1 WLR 1420; R (Begum) v Denbigh High School Governors [2006] UKHL 15, [2007] 1 AC 100.

27 See e.g. AR v Homefirst Community Trust [2005] NICA 8; Miss Behavin' Ltd v Belfast City Council [2005] NICA 35. 
be concerned with ensuring that their actions do not unjustifiably interfere with individual freedoms, as opposed to taking actions with a view to increasing the capacity of claimants to exercise their rights in the first place.

Question marks over the scope of application of rights, as I have just described them, highlight the importance of creating domestic legal frameworks which can provide effective protection for Convention rights and remedies when violations occur, in line with Starmer's principles as previously discussed. The experience of how the Human Rights Act - and, in particular, the obligations that flow from it - has been interpreted by courts in the United Kingdom is indicative of a wider concern that requires us to recognise the need for contextualised legislation. To ensure that they are practical and effective we must first acknowledge that human rights operate, as Jürgen Habermas suggests, within legal systems that are "also the expression of ... particular form[s] of life and not merely a reflection of the universal content of basic rights". 28 This was a point expressly recognised by the Belfast (Good Friday) Agreement when it provided the Northern Ireland Human Rights Commission (NIHRC) with a mandate to:

advise on the scope for defining, in Westminster legislation, rights supplementary to those in the European Convention on Human Rights, to reflect the particular circumstances of Northern Ireland, drawing as appropriate on international instruments and experience. These additional rights to reflect the principles of mutual respect for the identity and ethos of both communities and parity of esteem, and - taken together with the [Convention] - to constitute a Bill of Rights for Northern Ireland. ${ }^{29}$

Because a Bill of Rights for Northern Ireland must be progressive and build upon the Convention, it has presented an opportunity to deal with some of the issues that I have raised concerning the scope of application of rights. Here, the first point to be made is that, while the responsibilities of public authorities to uphold the Human Rights Act is narrowly outcome-focused, the Northern Ireland legal system within which the Act is situated more generally includes laws that require process-based compliance. Duties to eliminate discrimination found, for example, in the equality and good relations provisions of the Northern Ireland Act 1998 and Race Relations (Northern Ireland) Order 1997 contain strong procedural elements. ${ }^{30}$ They are, in other words, positive obligations that require actions to be taken. Schedule 9 to the Northern Ireland Act, in particular, includes a programmatic requirement that public authorities produce statutory schemes to be submitted to the Equality Commission for Northern Ireland. These schemes must demonstrate how the authority intends to implement the obligation to promote equality of opportunity and must cover arrangements for policy appraisal, including an assessment of impact on relevant groups, public consultation, public access to information and services, monitoring and timetables. 31

Further reflecting upon the observation made by Habermas - that human rights must be rendered effective within particular legal systems and will be coloured by that broader legal context - we should note that both the Belfast (Good Friday) Agreement and the Northern Ireland Act provide direction as to where the burden of responsibility should fall

28 Jürgen Habermas, "Struggles for recognition in the democratic constitutional state" in A Gutmann (ed.), Multiculturalism (Princeton, New Jersey: Princeton University Press 1994), p. 124.

29 The Agreement: Agreement reached in the multi-party negotiations (1998), pp. 16-17. For further discussion of this point see e.g. C Harvey and D Russell, "A new beginning for human rights protection in Northern Ireland?" (2009) EHRLR 748.

30 Northern Ireland Act 1998, s. 75; Race Relations (NI) Order 1997, Article 71(1).

31 Northern Ireland Act 1998, Sch. 9. 
for protecting, promoting and fulfilling human rights. The Agreement stipulates that the Northern Ireland Assembly, its Executive Committee and all other Northern Ireland public authorities must be bound by both the Convention and any Bill of Rights supplementing it. ${ }^{32}$ The mandate for a Bill of Rights also expressly states that, when determining the possible content, consideration must be given to the inclusion of "a clear formulation of the rights not to be discriminated against and to equality of opportunity in both the public and private sectors". ${ }^{33}$ Finally, because a Bill would be a regional instrument within part of the United Kingdom, it follows that consideration would need to be given to the relationship between it and all government institutions that have a competency in respect of the jurisdiction. There are three categories of government competence provided for by the Northern Ireland Act. First are "transferred matters", over which the devolved administration exercises power. Second are "reserved matters", over which Westminster exercises power, but which may be transferred with the consent of the Secretary of State. Third are "excepted matters", for which only Westminster can legislate, including areas such as the armed forces, immigration and electoral law. ${ }^{34}$

Considering this context, there is a compelling case to argue that, at a minimum, all public authorities in Northern Ireland would need to be obligated to act compatibly with a Bill of Rights that supplemented the Convention in order to ensure practical and effective legislation. It would also be necessary, given the experience of the Human Rights Act, to define a public authority so as to capture private, community and voluntary organisations that have entered into contractual arrangements to deliver frontline public services. For this reason, the NIHRC was correct in 2008 when it recommended that a public authority should include "any person or body performing a public function". 35 When it comes to transferred matters, as mentioned above, it seems reasonable to conclude that the Northern Ireland Assembly must be bound by a Bill of Rights. Similarly, it is important that reserved and excepted matters are both dealt with effectively, meaning that both the Westminster Parliament and central government public authorities should also be obliged to comply with a Bill. At present, designated public authorities that have a remit to carry out functions throughout the entirety of the United Kingdom, such as the Electoral Commission, ${ }^{36}$ must, when operating in or in relation to Northern Ireland, adhere to the requirement of s. 75 of the Northern Ireland Act 1998. ${ }^{37}$ By extension, and taking cognisance of the wider legal system, there are good grounds to suggest that, in so far as they perform their functions either in Northern Ireland or in relation to Northern Ireland, similar obligations should apply to both the Westminster Parliament and central government public authorities in respect of a Bill of Rights.

When determining the scope of application of rights and the point at which public and private organisations must take cognisance of their responsibilities, it is equally important to deal with the questions of where and when the burden of responsibility does not fall. Contextualised legislation that is effective must treat these issues in the round. There is a need to provide clarity on the questions raised and part of this will necessarily involve giving some reassurance that the responsibilities of public authorities will not be unduly onerous.

32 The Agreement, n. 29 above, s. 3 (5).

33 Ibid. s. 6 (4).

34 Northern Ireland Act 1998, s. 4.

35 A Bill of Rights for Northern Ireland: Advice to the Secretary of State for Northern Ireland (Belfast: NIHRC 2008), p. 149.

36 Northern Ireland Act 1998 (Designation of Public Authorities) Order 2004, Article 2.

37 See also Northern Ireland Act 1998 (Designation of Public Authorities) Order 2001 and Northern Ireland Act 1998 (Designation of Public Authorities) Order 2003. 
To this end, the text of the Convention would first need to be supplemented by making clear, as I have argued previously, that any proposed obligations are only attributable where an organisation defined as a public authority has competence to make a decision or devise a policy. It would be unreasonable, for example, to demand that a private sector company contracted for a specific purpose by government, such as hospital cleaning services or provision of public housing tenancies, be designated for all of their commercial activities. Second, what might be considered unreasonable should, as far as possible, be identified in advance through the introduction of qualifying clauses that aim, where appropriate, to reduce the burden of responsibility. This was certainly the approach adopted by the NIHRC in 2008. For example, the recommendation to supplement Article 2 of Protocol 1 to the Convention with a right that would enable everyone belonging to a linguistic minority "to learn or be educated in and through their minority language" also made clear that the concomitant obligation should accord with the viability test of there being a "substantial number of users and sufficient demand". 38 Once the scope of application is defined both in terms of when there is a duty to uphold human rights and when there is not it becomes possible to consider the types of positive obligations that could be introduced.

\section{Towards a typology for positive obligations}

Because the text of the Convention is by and large a guarantor for human rights conceived as negative liberties, an obvious way of supplementing its protections is by building upon the work of the ECtHR that, as I have already explained, has established case law that interprets the Convention as a treaty that requires governments "to take action" in order to protect rights and enable individual claimants to realise them in practice. ${ }^{39}$ It is most appropriate for domestic legislatures considering how to supplement the Convention, therefore, to attempt to spell out what some of these actions should involve and then move to enshrine them as free-standing protections. The justification for doing so is at least twofold. First, it would reflect the idea that practical and effective human rights need to be more than universal in character, or need to be premised upon more than general principles: they ought also to fit the particular contexts within which they are to operate. ${ }^{40}$ Second, it would afford domestic legislatures their rightful place to serve the interests of people residing within their jurisdictions by introducing laws that might pre-empt and perhaps even prevent the violation of existing human rights.

Drawing upon the advice given to the UK government on a proposed Bill of Rights for Northern Ireland by the NIHRC, I would like to suggest four ways in which positive obligations might be legislated for. First are directives, by which I mean duties laid down in legislation that require a government to take further legislative or policy actions in order to address a specific issue of concern and that are, therefore, outcome-based. Second are procedural duties, where public authorities are obligated to implement a process with the aim of creating the conditions where individual claimants are better placed to exercise their existing rights as they see fit. Third are programmatic duties, where the core of a positive obligation is outcome-focused, but its realisation is dependent upon a further requirement for the introduction of statutory schemes, such as impact assessments. Fourth is progressive realisation, which refers to those duties where deliberate concrete and targeted steps are required on behalf of duty-bearers, the aim being to increase over time both the level of obligation and the associated outcome. These formulations are not mutually exclusive nor

38 A Bill of Rights, n. 35 above, p. 104.

39 Gülv Switzerland (1996) 22 EHRR 93, dissenting opinion of Judge Martens, para. 7.

40 Habermas, "Struggles for recognition", n. 28 above, p. 124. 
are they exhaustive. In principle one, all or, indeed, any combination of these obligations could be introduced depending on the context.

\section{DIRECTIVES}

Directives require a government to take either legislative or policy actions to address a specific issue of concern. They are outcome-based to the extent that they demand a particular designated action to be taken with a view to achieving a specific objective. Significantly, the practical impact of a directive can also be process-based. Obligations of this sort may give rise, for example, to the introduction of statutory schemes for which a number of public authorities could hold collective responsibility. Crucially, though, those schemes would, given the nature of the obligation, be time-bound and focused upon achieving a pre-determined and measurable target. There are two examples of this approach that have been proposed for a Bill of Rights for Northern Ireland that can be pointed to by way of illustration. The first is a recommended provision that would direct the UK government to supplement Article 2 of the ECHR by legislating so as to ensure that all violations "relating to the conflict in Northern Ireland are effectively investigated". ${ }^{41}$ The second is a provision that would direct the government to address the needs of victims of the conflict through the introduction of legislation designed to "ensure that their rights are protected ... including rights to redress and to appropriate material, medical, psychological and social assistance". 42

In both of these instances, the positive obligations in question are associated with the specific task of introducing enabling legislation. Once that legislation was on the statute book, the respective obligations would be fulfilled and, hence, the individual provisions would no longer be a focus per se for exercising the rights that lie at the core of the issues which are to be addressed. Crucially, however, the positive obligations would remain as benchmarks against which the success or failure of any implementation processes could be tested. The Convention itself does not contain obligations of this sort, but useful precedents can be found in other international instruments. South Africa's Bill of Rights, for example, contains a number of directives. Article 25 states that:

A person or community whose tenure of land is legally insecure as a result of past racially discriminatory laws or practices is entitled, to the extent provided by an Act of Parliament, either to tenure which is legally secure or to comparable redress. ${ }^{43}$

Similarly, Article 32 calls for legislation to be enacted to give effect to the right to access "any information held by the state; and any information that is held by another person and that is required for the exercise or protection of any rights". 44

\section{Procedural DUTIES}

Procedural duties refer to circumstances where public authorities are obligated to implement a process with the aim of creating the conditions where individual claimants are better placed to exercise their existing rights as they see fit. This type of obligation can already be found within the Convention and has been further developed by the case law of the ECtHR. Article 6(3), as I have previously explained, is a good example of a procedural duty. The requirement that contracting states ensure the right to a fair trial carries with it an

41 A Bill of Rights, n. 35 above, pp. 61-2.

42 Ibid. pp. 108-9.

43 Constitution of the Republic of South Africa 1996, s. 25(6).

44 Ibid. Article 32(1) and (2). 
obligation to formulate processes that will create the necessary conditions under which this right can be fulfilled. So, for example, it is important to ensure that everyone charged with a criminal offence can consult with a legal representative. ${ }^{45}$ There are a number of examples of a procedural approach recommended for inclusion in a Bill of Rights for Northern Ireland that further illustrate how duties of this sort can be constructed. In the case of children, it has been suggested that the Convention might be supplemented by including a provision aimed at ensuring that:

every child alleged to, accused of, or proven to have infringed the criminal law has the right to be treated in a manner that pays due regard to the child's age, understanding, and needs and is directed towards the child's reintegration in society. ${ }^{46}$

In many cases, procedural duties may already be afforded protection within a broader legal framework. But, even when this is the case, there can be strong reasons for spelling out what a particular obligation is understood to mean in practice. The Convention and jurisprudence have gone some way toward developing procedural duties already, but it is also possible to draw examples from other international instruments. The provision of special assistance for children during a criminal trial recommended for inclusion in the Bill of Rights for Northern Ireland draws upon the UN's Convention on the Rights of the Child, which states in Article 37 that:

Every child deprived of liberty shall be treated with humanity and respect for the inherent dignity of the human person, and in a manner which takes into account the needs of persons of his or her age. ${ }^{47}$

It also makes reference to the UN's International Covenant on Civil and Political Rights, Article 14 of which demands on ground of equality before a court that juveniles are subjected to procedures that "take account of their age and the desirability of promoting their rehabilitation". 48

\section{Programmatic duties}

Programmatic duties are those where the core of a positive obligation is outcome-focused, but its realisation is dependent upon a further requirement for the introduction of statutory schemes such as impact assessments. Here, a clear statement that sets out the nature of the duty in question and, in particular, the responsibilities that are attached to it are important. This is because the reach of programmatic duties can vary considerably. The difference between demanding that public authorities take all appropriate measures, have due regard, or have regard to the desirability of promoting, protecting and fulfilling an obligation cannot be overstated. Where an obligation requires "all appropriate measures" to be taken or indicates that public authorities "must" carry out an action, the fulfilment of the duty is an immediate requirement. By contrast, where the duty is to "have due regard", there is arguably a greater flexibility when it comes to a public authority initiating a programme for implementation.

Similar to procedural duties, programmatic duties may already be situated within the context of a broader legal framework. However, whereas the purpose of introducing a procedural duty is to enable the better exercising of other existing rights, a programmatic

45 See e.g. Averill v UK (2001) 31 EHRR 36 ECHR, paras 57-8 and Murray v UK (1996) 22 EHRR 29, paras 72-4.

46 A Bill of Rights, n. 35 above, pp. 68-9.

47 Article 37(c).

48 Article 14(4). 
duty is a good in itself. So, when the NIHRC recommended including in a Bill of Rights for Northern Ireland a provision that:

public authorities must encourage a spirit of tolerance and dialogue, taking effective measures to promote mutual respect, understanding and co-operation among all persons living in Northern Ireland, irrespective of those persons' race, ethnicity, language, religion or political opinion ${ }^{49}$

it did so in the knowledge that a similar - but narrower and less rigorous - obligation was already contained within the Northern Ireland Act 1998. The commission was minded nonetheless to recommend enshrining a duty of this sort, given that the particular circumstances of Northern Ireland meant that it would serve an important public interest. ${ }^{50}$

Once again, useful precedents can be found in a number of international instruments. The commission's recommendation that I have used here by way of example is analogous to Article 6 of the Council of Europe's Framework Convention for the Protection of National Minorities, which requires contracting states to:

encourage a spirit of tolerance and intercultural dialogue and take effective measures to promote mutual respect and understanding and co-operation among all persons living on their territory, irrespective of those persons' ethnic, cultural, linguistic or religious identity, in particular in the fields of education, culture and the media.

The commission itself refers in its advice to Article 1 of the UN's Declaration on the Rights of Persons Belonging to National or Ethnic, Religious and Linguistic Minorities, which requires protection to be given to "the existence and the national or ethnic, cultural, religious and linguistic identity of minorities" and encouragement of "conditions for the promotion of that identity".

\section{Progressive REALISATION}

Progressive realisation refers to those duties where "deliberate, concrete and targeted" 51 steps are required on behalf of duty-bearers, the aim being to increase over time both the level of obligation and associated outcome. Some human rights, notably those that are social or economic in character, such as health, education and work, may require extra resource commitments on the part of a government before they can be fully realised in practice. But those resources will not always be readily available. It is a challenge for any democratic government to balance its response when faced with competing priorities and a limited budget. For this reason, progressive realisation does not require that the results sought from enshrining a particular right be achieved immediately, but instead demands that all appropriate measures be taken towards meeting that objective, moving as expeditiously and effectively as possible. It is important to note that whilst some rights may be realised over time, crucially this does not render void the associated obligations of a substantive meaning. Each right which is subject to progressive realisation will always contain what has been described as a "minimum core obligation" that is immediately enforceable. Furthermore,

49 A Bill of Rights, n. 35 above, p. 103.

50 Northern Ireland Act 1998, s. 75(2). This recommendation would widen the reach of s. 75 from three categories (race, religion and political opinion) to five, adding ethnicity and language. It would also raise the level of the obligation. Rather than having due regard to the desirability of implementing the duty as currently conceived by s. 75 , public authorities would be required to demonstrate effective measurable outcomes. The status of the good relations duty would therefore change from something that has often been seen as a bolton to equality of opportunity to become instead a positive obligation with independent standing.

51 UN Committee on Economic, Social and Cultural Rights, General Comment No. 3 (1990) on the Nature of States Parties' Obligations, para. 2. 
that core should demonstrably increase with the passage of time and a government should report on a regular basis in a public forum as to how this is being achieved. ${ }^{52}$

In the case of Northern Ireland, a number of social and economic rights recommended for inclusion in a regional Bill of Rights include obligations for progressive realisation. For example, it has been proposed that everyone should have "the right to adequate accommodation appropriate to their needs" and that "public authorities must take all appropriate measures, including legislative measures, to the maximum of their available resources, with a view to achieving progressively the full realisation of this right". 53 It is also suggested that:

[w] here rights are subject to progressive realisation, the Northern Ireland Executive shall report annually to the Northern Ireland Assembly, and the [UK] Government shall report annually to Parliament, on the progress made during the previous year in realising these rights in Northern Ireland. ${ }^{54}$

Although the Convention does not itself contain obligations of this type, once again useful examples can be found by examining other international instruments. Article 2 of the UN's International Covenant on Economic, Social and Cultural Rights calls upon each contracting state to:

take steps, individually and through international assistance and co-operation, especially economic and technical, to the maximum of its available resources, with a view to achieving progressively the full realization of the rights recognized in the present Covenant by all appropriate means, including particularly the adoption of legislative measures. ${ }^{55}$

South Africa's Bill of Rights also contains a number of such obligations, including Article 26 which states that "[e]veryone has the right to have access to adequate housing" and that "the state must take reasonable legislative and other measures, within its available resources, to achieve the progressive realisation of this right". 56

\section{Conclusion}

In this paper I have sought to demonstrate how we can identify principles that underpin, at a general level, a reading of the ECHR to include positive obligations. Keir Starmer's principles are general requirements that any government would have to adhere to in order to uphold the Convention as a text supportive of positive obligations. But I also believe that these same principles could apply to any human rights framework: a government would need to take actions to secure equal rights for everyone within its jurisdiction, it would have to take actions to guarantee that those rights were both practical and effective, and it would have to secure effective remedies when violations occur. However, I have argued that these general principles need to be applied in a context-sensitive manner, and that we therefore need to move from the general level to the particular. I have also argued that the task of

52 See e.g. the reporting requirements for progressive realisation imposed on contracting states by the UN's International Covenant on Economic, Social and Cultural Rights, Part IV.

53 A Bill of Rights, n. 35 above, pp. 118-19.

54 Ibid. p. 165. An interesting observation is that Northern Ireland may be strongly positioned as a consequence of the practical operation of devolution to implement positive obligations of this sort. Because the devolved administration publishes a Programme for Government, the delivery framework for which includes robust and effective monitoring, there is an already established foundation from which the executive could report annually to the Assembly on a Bill of Rights and those provisions that include progressive realisation. See, Northern Ireland Executive, Building a Better Future - Programme for Government 2008-2011 (2008).

55 Article 2(1).

56 Article 26(6). 
determining positive obligations should not be left to the courts, but should be a matter of legislative concern.

Northern Ireland demonstrates why a context-sensitive approach to positive obligations is necessary, what that might mean in practice, and why legislation is the best means of achieving a satisfactory outcome. In this example, the general principles of securing equal rights for everyone, guaranteeing that those rights are practical and effective, and securing effective remedies have been manifested in the call for a regional Bill of Rights. The need to extend the scope of application of rights to include a wider definition of public authority and to provide a clearer indication of where the burden of responsibility ought to lie to promote, protect and fulfil human rights is demonstrable. But perhaps most interesting of all in the case of Northern Ireland is that, by thinking through a context-sensitive approach that seeks to supplement the ECHR, it has been possible to reflect back upon the general principles which underpin positive obligations and to identify how we can build upon those principles and develop them still further. A typology that stems from a single case study, but one that has been informed by a principled reading of the Convention, that draws upon international instruments and legislation from other jurisdictions, is a strong basis for future discussion. What is at any rate clear is that there is a great deal more work to be done in thinking about positive obligations. But, since there is so much at stake, there is every reason to pursue this agenda further. 